\title{
Genetic parameters for rennet- and acid-induced coagulation properties in milk from Swedish Red dairy cows
}

\author{
F. Gustavsson, ${ }^{* 1,2}$ M. Glantz, ${ }^{* 1}$ N. A. Poulsen,† L. Wadsö,‡ H. Stålhammar,§ A. Andrén,\# \\ H. Lindmark Månsson, ${ }^{*}$ I L. B. Larsen,† M. Paulsson, ${ }^{*}$ and W. F. Fikseף \\ ${ }^{*}$ Department of Food Technology, Engineering and Nutrition, Lund University, PO Box 124, SE-221 00 Lund, Sweden \\ †Department of Food Science, Faculty of Science and Technology, Aarhus University, Blichers Allé 20, PO Box 50, DK-8830 Tjele, Denmark \\ ‡Department of Building Materials, Lund University, PO Box 118, SE-221 00 Lund, Sweden \\ §VikingGenetics, PO Box 64, SE-532 21 Skara, Sweden \\ \#Department of Food Science, BioCenter, Swedish University of Agricultural Sciences, PO Box 7051, SE-750 07 Uppsala, Sweden \\ IILRF Dairy Sweden, Ideon Science Park, SE-223 70 Lund, Sweden \\ TDepartment of Animal Breeding and Genetics, Swedish University of Agricultural Sciences, PO Box 7023, SE-750 07 Uppsala, Sweden
}

\begin{abstract}
Milk coagulation is an important processing trait, being the basis for production of both cheese and fermented products. There is interest in including technological properties of these products in the breeding goal for dairy cattle. The aim of the present study was therefore to estimate genetic parameters for milk coagulation properties, including both rennet- and acid-induced coagulation, in Swedish Red dairy cattle using genomic relationships. Morning milk samples and blood samples were collected from 395 Swedish Red cows that were selected to be as genetically unrelated as possible. Using a rheometer, milk samples were analyzed for rennetand acid-induced coagulation properties, including gel strength $\left(G^{\prime}\right)$, coagulation time, and yield stress (YS). In addition to the technological traits, milk composition was analyzed. A binary trait was created to reflect that milk samples that had not coagulated 40 min after rennet addition were considered noncoagulating milk. The cows were genotyped by using the Illumina BovineHD BeadChip (Illumina Inc., San Diego, CA). Almost 600,000 markers remained after quality control and were used to construct a matrix of genomic relationships among the cows. Multivariate models including fixed effects of herd, lactation stage, and parity were fitted using the ASReml software to obtain estimates of heritabilities and genetic and phenotypic correlations. Heritability estimates $\left(h^{2}\right)$ for $\mathrm{G}^{\prime}$ and YS in rennet and acid gels were found to be high $\left(h^{2}=0.38-0.62\right)$ and the genetic correlations between rennet-induced and acid-induced coagulation properties were weak but favorable, with the exception of $\mathrm{YS}_{\text {rennet }}$ with $\mathrm{G}_{\text {acid }}^{\prime}$ and
\end{abstract}

\footnotetext{
Received January 30, 2014.

Accepted April 29, 2014.

${ }^{1}$ These authors contributed equally to the paper.

${ }^{2}$ Corresponding author: frida.gustavsson@food.lth.se
}

$\mathrm{YS}_{\text {acid }}$, both of which were strong. The high heritability $\left(h^{2}=0.45\right)$ for milk coagulating ability expressed as a binary trait suggests that noncoagulation could be eliminated through breeding. Additionally, the results indicated that the current breeding objective could increase the frequency of noncoagulating milk and lead to deterioration of acid-induced coagulation through unfavorable genetic associations with protein content (0.38) and milk yield $(-0.61$ to -0.71$)$, respectively. The outcome of this study suggests that by including more detailed compositional traits genetically associated with milk coagulation or by including milk coagulation properties directly within the breeding goal, it appears possible to breed cows that produce milk better suited for production of cheese and fermented products.

Key words: milk coagulation, genetic correlation, heritability, noncoagulating milk

\section{INTRODUCTION}

There is increased interest to include technological properties and more detailed milk composition traits in the breeding goal for dairy cattle (Boichard and Brochard, 2012). Because of this, it is necessary to estimate genetic parameters for these traits. Milk coagulation is an important processing trait, being the basis for the production of cheese and fermented products. In Sweden, $45 \%$ of total cow milk production is processed into cheese and fermented products; $36 \%$ of total milk production goes to cheese manufacturing (International Dairy Federation, 2012). Additionally, the production of cheese and fermented products is expected to increase worldwide during the coming years (International Dairy Federation, 2012). Adding milk coagulation properties to the breeding goal would improve raw milk quality and thus increase the economic output for the dairy industry by improved processing parameters for these products. 
Rennet- and acid-induced coagulation are two of the most common milk coagulation processes. Both are based on destabilization of $\mathrm{CN}$ micelles, leading to aggregation (Lucey, 2009). Rennet-induced coagulation is the first step in cheese production. In this step, rennet destabilizes the $\mathrm{CN}$ micelles in the milk by hydrolysis of $\kappa$-CN, making the $\mathrm{CN}$ micelles aggregate to form a coagulum (Dalgleish, 1992; Walstra et al., 2006; Lucey, 2009). In contrast, acid-induced coagulation is applied in the production of fermented products such as yogurt. As a pretreatment, the milk is heated to approximately 90 to $95^{\circ} \mathrm{C}$ for 5 to $10 \mathrm{~min}$ to denature the whey proteins, mainly $\beta-\mathrm{LG}$, which (in addition to self-aggregation) will interact with $\kappa-\mathrm{CN}$ and $\alpha_{\mathrm{S}^{-}}$ CN on the CN micelles (Lucey and Singh, 1998; Lucey, 2002; Guyomarc'h et al., 2003). Acidification causes the $\mathrm{pH}$ to decrease such that, at $\mathrm{pH} 4.6$, the net negative charge of the $\mathrm{CN}$ micelles is neutralized and a protein gel network is formed (Lucey and Singh, 1998; Lucey, 2009). Several milk composition traits have been shown to affect the properties of both rennet-induced gels (Ikonen et al., 2004; Wedholm et al., 2006; Amenu and Deeth, 2007) and acid-induced gels (Lucey and Singh, 1998; Allmere et al., 1999; Hallén et al., 2009), including contents of protein, $\mathrm{CN}$, whey proteins, fat, and lactose, as well milk $\mathrm{pH}$, traits that could thus be used as indicators for milk coagulation properties. However, it is important to elucidate the genetic correlations between these traits and milk coagulation properties to define suitable breeding goals.

Several studies have reported heritabilities for coagulation time $(\mathbf{C T})$ and gel strength $\left(\mathbf{G}^{\prime}\right)$ in rennet gels as reviewed by Bittante et al. (2012), with average heritability estimates of 0.26 (SD 0.06) and 0.27 (SD 0.11 ), respectively, showing the potential to change these properties through breeding. For milk composition traits, including fat, protein, $\mathrm{CN}$, and lactose contents and milk yield, heritabilities are reported to range from 0.07 to 0.66 (e.g., Schopen et al., 2009; Penasa et al., 2010; Tiezzi et al., 2013). Furthermore, genetic correlations between rennet coagulation properties and milk composition traits have been reported, although the results are contradictory (Ikonen et al., 2004; Cassandro et al., 2008; Cecchinato et al., 2011). However, to our knowledge, no studies have reported heritabilities or genetic correlations for acid-induced coagulation properties. Genetic parameters are usually estimated based on pedigree relationships (Bittante et al., 2012); however, some uncertainty always exists in national pedigree databases (K. Johansson, Växa Sverige, Stockholm, Sweden, personal communication), which affects further estimations of genetic parameters. Therefore, using genomic data could give more accurate estimations (Veerkamp et al., 2011).
The aim of the present study was to estimate genetic parameters for milk coagulation properties, including both rennet- and acid-induced coagulation, in Swedish Red (SR) dairy cattle using genomic relationships. This study will give information on genetic relationships for milk coagulation properties that can be used to improve the current breeding goal and implement new traits within national breeding programs. To our knowledge, this is the first time that genetic parameters have been estimated for rennet-induced coagulation properties in SR and for acid-induced coagulation properties in any dairy cattle breed.

\section{MATERIALS AND METHODS}

\section{Milk and Blood Sampling}

As part of the Danish-Swedish Milk Genomics Initiative, morning milk samples and blood samples were collected from 395 SR cows during the indoor period from April to May 2010 as well as September 2010 to April 2011. The sampled cows, which originated from 20 conventional farms located in the same geographical region in the southern part of Sweden, were fed according to standard practices and milked 2 or 3 times per day. The cows were selected to be as genetically unrelated as possible; the cows were progenies of 160 different sires. Data were obtained for lactation stage and parity, ranging from wk 3 to 61 ( $2 \%$ before lactation wk 7 and $10 \%$ after lactation wk 40) and parity 1 to 4 ( $1 \%$ in parity 4 ), respectively. A representative aliquot of each milk sample was collected and cooled for further transport to Lund University (Lund, Sweden) and Aarhus University (Aarhus, Denmark) on the same day as sampling. After arriving at Lund University, the samples were defatted by centrifugation at $2,000 \times g$ for $30 \mathrm{~min}$ to reduce the number of variables influencing coagulation properties. Furthermore, the samples were subsampled and stored at either $4^{\circ} \mathrm{C}$ or $-20^{\circ} \mathrm{C}$ until further analyses.

\section{Milk Composition}

The contents of total protein, CN, fat, and lactose in fresh milk samples were predicted by infrared spectroscopy (MilkoScan FT2, Foss Electric, Hillerød, Denmark). Somatic cell count was analyzed in fresh milk samples using flow cytometry (Combifoss 5000, Foss Electric) at a certified dairy analysis laboratory (Eurofins Steins Laboratory, Jönköping, Sweden). The fresh milk samples were analyzed the day after sampling. Furthermore, relative concentrations of $\kappa-\mathrm{CN}$ and $\beta-\mathrm{LG}$ relative to total protein content were determined by capillary zone electrophoresis according to Gustavsson 
et al. (2014). The relative concentration of $\kappa$ - $\mathrm{CN}$ was defined as the nonglycosylated monophosphorylated form of $\kappa-\mathrm{CN}$. Test-day milk yields from the official milk recording closest to the day of sampling were collected from the national cow database.

\section{Rennet-Induced Coagulation}

Fresh skim milk samples were preserved with bronopol (Sigma-Aldrich, Schnelldorf, Germany) by adding a bronopol solution of $17 \%$ (wt/vol) to all milk samples (2 $\mu \mathrm{L} / \mathrm{mL}$ ), according to Hallén et al. (2007). The samples were stored at $4^{\circ} \mathrm{C}$ until rheological measurements, although no longer than $3 \mathrm{~d}$. Milk samples were heated to $32^{\circ} \mathrm{C}$ for $30 \mathrm{~min}$ before chymosin $(0.44 \mathrm{~mL} / \mathrm{L}$ Chy-Max Plus, 205 international milk clotting units (IMCU)/mL, Chr. Hansen A/S, Hørsholm, Denmark) was added and the solution was gently stirred. Lowamplitude oscillation measurements were performed at $32^{\circ} \mathrm{C}$ during 40 min using a Stresstech rheometer (ReoLogica Instruments AB, Lund, Sweden) as described by Glantz et al. (2009), with modifications as reported by Glantz et al. (2011). The addition of chymosin corresponded to time zero. Rennet gel strength $\left(\mathbf{G}^{\prime}{ }^{\prime}\right.$ ennet $)$ was defined as the elastic or storage modulus, $\mathrm{G}^{\prime}$, after $40 \mathrm{~min}$ of coagulation, where $\mathrm{G}^{\prime}=\sigma_{0} / \gamma_{0} \cdot \cos \delta$, and $\sigma_{0}$ $=$ maximum stress, $\gamma_{0}=$ maximum shear strain, and $\delta=$ phase angle (phase difference between strain and stress). Rennet coagulation time $\left(\mathbf{C T}_{\text {rennet }}\right)$ was defined as the point in time when a continuous increase in $\mathrm{G}^{\prime}$ was detected by the instrument. After $40 \mathrm{~min}$ of coagulation, a stress sweep was performed according to Glantz et al. (2011) to obtain the yield stress (YS), which is a measure of large deformation properties. The YS of rennet-induced gels $\left(\mathbf{Y S}_{\text {rennet }}\right)$ was defined as the shear stress at the point where the viscosity reached $90 \%$ of the maximum recorded viscosity. Some samples were unable to coagulate within 40 min of measurement and were considered noncoagulating (NC; $18 \%$ of the samples).

\section{Acid-Induced Coagulation}

To obtain representative samples, skim milk was thawed at $4^{\circ} \mathrm{C}$ overnight and prewarmed in a water bath at $30^{\circ} \mathrm{C}$ for $30 \mathrm{~min}$. The samples $(40 \mathrm{~mL})$ were heat treated at $95^{\circ} \mathrm{C}$ for $5 \mathrm{~min}(10 \mathrm{~min}$ in total including heating up) and cooled on ice to $30^{\circ} \mathrm{C}$. Glucono$\delta$-lactone (GDL; Sigma-Aldrich, St. Louis, MO) was added to $3 \%$ (wt/vol) and the samples were carefully mixed. Acid-induced coagulation was carried out with low-amplitude oscillation measurements for $60 \mathrm{~min}$ at a frequency of $1 \mathrm{~Hz}$ using a Kinexus rheometer (Malvern Instruments Ltd., Malvern, UK). The temperature was held constant at $30^{\circ} \mathrm{C}$ and the geometry used was a vane and cup (geometry 4V21:PC25). Strain sweep measurements were performed to determine the linear viscoelastic region of the acid milk gels and hence appropriate strain levels. A controlled strain at 0.003 was used for the low-amplitude oscillation measurements. The addition of GDL corresponded to time zero. Acid gel strength $\left(\mathbf{G}^{\prime}\right.$ acid $)$ and acid coagulation time $\left(\mathbf{C T}_{\text {acid }}\right)$ were derived from the obtained results, where $\mathrm{G}^{\prime}$ acid was defined as $\mathrm{G}^{\prime}$ after 60 min of coagulation, and $\mathrm{CT}_{\text {acid }}$ was defined as the time when $\mathrm{G}^{\prime \prime}=\mathrm{G}^{\prime}$, where $\mathrm{G}^{\prime \prime}=\sigma_{0} /$ $\gamma_{0} \cdot \sin \delta, \sigma_{0}=$ maximum stress, $\gamma_{0}=$ maximum shear strain, and $\delta=$ phase angle (phase difference between strain and stress). Following gel formation, stress sweeps were run to study the stress dependence of the viscosity to obtain the YS of acid-induced gels ( $\left.\mathbf{Y S}_{\text {acid }}\right)$. The shear stress was increased in 126 intervals from 1 to $300 \mathrm{~Pa}$, and $\mathrm{YS}_{\text {acid }}$ was defined as the shear stress at the first local maximum of the viscosity.

\section{Acidification Rate Constant}

The acidification rate constant (ARC) during acidinduced coagulation, which is an indirect measure of fermentation kinetics, was determined from isothermal calorimetric measurements. A subset of the sample set was selected based on high and low relative concentration of $\beta-\mathrm{LG}$ and $\mathrm{CN}$ number (CN/total protein) and, in total, 112 samples were analyzed. Skim milk samples were thawed, preheated, and heat treated in the same way as for the acid-induced coagulation measurements before $15 \mathrm{~mL}$ of skim milk was transferred to glass ampules that were closed with rubber stoppers and placed in a heating block at $30^{\circ} \mathrm{C}$ for $10 \mathrm{~min}$. Then, GDL was added to the skim milk to $1.5 \%$ (wt/vol) and the sample was carefully mixed before it was transferred to a calorimeter [TAM Air isothermal heat conduction calorimeter, Thermometric AB (now TA Instruments), Järfälla, Sweden] for continuous measurements of heat production rate during $6 \mathrm{~h}$ at $30^{\circ} \mathrm{C}$. The addition of GDL corresponded to time zero. The reference ampules were filled with the same mass of distilled water as the mass of milk sample to reduce the noise level of the signal.

The specific heat production rate was calculated using Eq. [1]:

$$
p=\varepsilon \frac{U_{\mathrm{S}}-U_{\mathrm{BL}}}{m},
$$

where $p$ is the heat production rate $(\mathrm{mW} / \mathrm{g}), \varepsilon$ is the calibration coefficient of the calorimeter $(\mathrm{mW} / \mathrm{mV}), U_{\mathrm{S}}$ is the voltage signal from the calorimeter $(\mathrm{mV}), U_{\mathrm{BL}}$ is the corresponding voltage recorded for the baseline 
$(\mathrm{mV})$, and $m$ is the mass of the sample $(\mathrm{g})$. The calibration coefficients were calculated from electrical calibrations made at $30^{\circ} \mathrm{C}$, and the baselines were measured with $20 \mathrm{~mL}$ of water in both sample and reference. The Tian equation (Eq. [2]) was used to obtain the correct heat production rate by removing the effect of the instrument's thermal inertia:

$$
p_{\mathrm{C}}=p+\tau \frac{\mathrm{d} p}{\mathrm{~d} t},
$$

where $p_{\mathrm{C}}$ is the corrected thermal power, $\tau$ is the time constant (s), and $\mathrm{d} p / \mathrm{d} t$ is the derivative of the heat production rate with respect to time. The time constant is a measure of the thermal inertia of the sample-calorimeter combination and depends on the sample heat capacity and heat transfer properties of the calorimeter (Wadsö, 2005). The time constant was calculated from the heat capacity of the sample, the ampoule, ampoule holder, and the thermal conductance of the calorimeter (Wadsö, 2010). Each sample was analyzed in duplicate. The calorimetry results showed that the GDL process followed first-order kinetics. The ARC was used as a measure of the intensity of the process and was calculated from the slope between approximately 2 and $5 \mathrm{~h}$ of the logarithm of the heat production rate as a function of time, similar to that shown in Wadsö and Li (2008).

\section{Genotyping}

Cows were genotyped for 777,000 SNP with the Illumina BovineHD BeadChip (Illumina Inc., San Diego, CA) at GenoSkan A/S (Foulum, Denmark). All 395 animals had a call rate $>95 \%$. The genotypic data were edited by loci. Marker loci were excluded if their minor allele frequency was $<1 \%$, the proportion of animals called for a marker locus was $<95 \%$, or the average GenCall score (Illumina Inc.) was $<0.65$. Marker loci without a map position in the Bos taurus genome assembly (Btau_4.0; Liu et al., 2009) were discarded. Single nucleotide polymorphisms on the $\mathrm{X}$ chromosome were excluded. After these edits, a total of 599,359 SNP were left for analysis. Individual SNP marker results were also removed if their GenCall score was $<0.6$. Missing genotypes on individual loci were imputed using Beagle version 3.3 (Browning and Browning, 2007).

\section{Data Editing}

Data from milk samples with $\mathrm{SCC}>500,000$ cells/ $\mathrm{mL}$ were discarded from the analysis. We verified the absence of outlier observations for the analyzed variables, where an observation was considered as outlier if it departed more than 4 standard deviation units from the mean. All milk coagulation variables were transformed with a Box-Cox transformation to improve the distributional properties of the data. Casein content was subjected to an arctan transformation to reduce the kurtosis. The variable $\mathrm{NC}_{\text {rennet }}$ was defined to be able to avoid bias in estimated genetic parameters due to $\mathrm{NC}$ samples; $\mathrm{NC}_{\text {rennet }}$ was derived from the variable $\mathrm{CT}_{\text {rennet }}: 0$ if $\mathrm{CT}_{\text {rennet }}<40 \mathrm{~min}, 1$ if $\mathrm{CT}_{\text {rennet }} \geq$ 40 min. Almost $18 \%$ of the samples were defined as $\mathrm{NC}$ in rennet-induced coagulation; however, all samples coagulated within the time of measurement in acidinduced coagulation. As a consequence, the number of observations was lower for rennet-induced coagulation properties than for acid-induced coagulation properties (Table 1). The remaining variation in the number of observations was partly because some samples yielded indeterminate results.

\section{Statistical Analyses}

Statistical analyses were based on the 395 animals that had both phenotypic and genotypic information. Information about systematic environmental effectsherd, lactation stage, and lactation number-were included as fixed effects in the statistical model. Thus, the following model (Eq. [3]) was used in the analysis:

$$
\begin{aligned}
y_{\mathrm{ijk}} & =\mu+\operatorname{herd}_{i}+\operatorname{lactation}_{j}+b \\
& \times \text { l_stage }+\operatorname{animal}_{k}+e_{i j k},
\end{aligned}
$$

where $y_{i j k}$ is the phenotype of individual $k$ in herd $i$ and lactation $j, \mu$ is the fixed mean effect, herd is a fixed effect $(i=1,2, \ldots, 20)$, lactation is a fixed effect of lactation number $(j=1,2,3$; lactation numbers 3 and 4 were combined because of the small number of observations in lactation 4$), b$ is a fixed regression on lactation stage (1_stage), and animal is the random additive genetic effect of animal $k$. Relationships between animals were calculated on the basis of the marker data, as described by VanRaden (2008).

Genetic correlations were estimated in 4 steps. First, parameters for rennet-induced coagulation properties were estimated in a multivariate analysis. Second, parameters for acid-induced coagulation properties were estimated in a multivariate analysis. Third, associations among rennet- and acid-induced coagulation properties were estimated in a multivariate analysis. Fourth, correlations between rennet-induced coagulation properties and milk composition traits were estimated in several multivariate analyses, each including all rennet-induced coagulation properties and one of the milk composition traits. Correlations between acid-induced coagulation 
Table 1. Means, standard deviations (SD), and heritability $\left(h^{2}\right)$ estimates $^{1}$ with standard errors (SE) for milk coagulation properties and milk composition in Swedish Red cows

\begin{tabular}{|c|c|c|c|c|c|}
\hline Trait $^{2}$ & $\begin{array}{c}\text { No. of } \\
\text { samples }\end{array}$ & Mean & SD & $h^{2}$ & $\mathrm{SE}$ \\
\hline $\mathrm{NC}_{\text {rennet }}$ & 382 & 0.18 & 0.38 & 0.45 & 0.12 \\
\hline $\mathrm{G}_{\text {remnet }}^{\prime}(\mathrm{Pa})$ & 297 & 78.0 & 63.0 & 0.53 & 0.15 \\
\hline $\mathrm{CT}_{\text {rennet }}(\mathrm{min})$ & 314 & 14.6 & 7.8 & - & - \\
\hline $\mathrm{YS}_{\text {rennet }}(\mathrm{Pa})$ & 293 & 15.7 & 5.8 & 0.43 & 0.18 \\
\hline $\mathrm{G}_{\text {acid }}^{\prime}(\mathrm{Pa})$ & 363 & 222.5 & 62.1 & 0.62 & 0.14 \\
\hline $\mathrm{CT}_{\text {acid }}(\min )$ & 363 & 18.0 & 3.6 & 0.00 & - \\
\hline $\mathrm{YS}_{\text {acid }}(\mathrm{Pa})$ & 363 & 28.3 & 10.4 & 0.38 & 0.14 \\
\hline Acidification rate constant $\left(\mathrm{s}^{-1}\right)$ & 109 & $15.0 \times 10^{-5}$ & $1.4 \times 10^{-5}$ & 0.93 & 0.38 \\
\hline Milk yield (kg) & 384 & 29.4 & 8.0 & 0.21 & 0.14 \\
\hline Protein (g/100 g) & 362 & 3.6 & 0.4 & 0.41 & 0.13 \\
\hline $\mathrm{CN}(\mathrm{g} / 100 \mathrm{~g})$ & 362 & 2.6 & 0.1 & 0.24 & 0.12 \\
\hline Fat $(\mathrm{g} / 100 \mathrm{~g})$ & 362 & 4.1 & 0.9 & 0.38 & 0.15 \\
\hline Lactose (g/100 g) & 362 & 4.7 & 0.1 & 0.15 & 0.15 \\
\hline$\beta-\mathrm{LG}(\mathrm{wt} / \mathrm{wt} \%)^{3}$ & 310 & 8.8 & 1.8 & 0.59 & 0.16 \\
\hline$\kappa-\mathrm{CN}(\mathrm{wt} / \mathrm{wt} \%)$ & 310 & 5.3 & 1.0 & 0.37 & 0.16 \\
\hline
\end{tabular}

${ }^{1}$ After transformation; all $h^{2}$, except those for $\mathrm{CT}_{\text {acid }}$ and lactose content, deviated more than $1.645 \times \mathrm{SE}$ from $0(P<0.05)$.

${ }^{2} \mathrm{NC}_{\text {rennet }}$ is a binary trait, where $0=$ coagulated, $1=$ noncoagulated; $\mathrm{G}^{\prime}=$ gel strength; $\mathrm{CT}=$ coagulation time; YS = yield stress.

${ }^{3}$ Weight per total protein weight.

properties and milk composition traits were estimated similarly. Several of the correlations were estimated multiple times and, for each correlation, we reported a single estimate obtained from the analysis with lowest number of traits. That is, genetic correlations among rennet-induced properties were taken from the first step, genetic correlations among acid-induced coagulation properties were taken from the second step, and the remaining correlations (all estimated only once) were taken from steps 3 and 4 .

Preliminary single-trait genetic analysis of all coagulation properties revealed no detectable genetic variation for $\mathrm{CT}_{\text {acid }}$ and this trait was discarded from further genetic analysis. Further, as $\mathrm{NC}_{\text {rennet }}$ was defined on the basis of $\mathrm{CT}_{\text {rennet }}$ and included in the multivariate analyses of rennet coagulation traits, $\mathrm{CT}_{\text {rennet }}$ was not used in the genetic analyses. The trait $\mathrm{NC}_{\text {rennet }}$ was analyzed as a normally distributed trait, despite its binary nature, as more sophisticated models, as discussed by Cecchinato and Carnier (2011), failed to produce meaningful results.

To estimate the genetic parameters and variance components, ASReml was used (Gilmour et al., 2009). Heritability was defined according to Eq. [4]:

$$
h_{i}^{2}=\sigma_{a, i}^{2} /\left(\sigma_{a, i}^{2}+\sigma_{e, i}^{2}\right) \text {, }
$$

where $\sigma_{a, i}^{2}$ was the genetic variation and $\sigma_{e, i}^{2}$ the residual variation for trait $i$. Genetic and phenotypic correlations $\left(r G_{i, j}\right.$ and $\left.r P_{i, j}\right)$ were computed according to Eq. $[5]$ and [6], respectively:

$$
\begin{aligned}
& r G_{i, j}=\sigma_{a, i ; a, j} /\left(\sigma_{a, i}^{2} \times \sigma_{a, j}^{2}\right) \\
& r P_{i, j}=\sigma_{p, i ; p, j} /\left(\sigma_{p, i}^{2} \times \sigma_{p, j}^{2}\right),
\end{aligned}
$$

where $\sigma_{a, i ; a, j}$ was the genetic covariance between traits $i$ and $j$, and $\sigma_{p, i ; p, j}$ was the phenotypic covariance between traits $i$ and $j$, calculated as $\sigma_{a, i ; a, j}+\sigma_{e, i ; e, j}$.

\section{RESULTS AND DISCUSSION}

This study reports estimations of genetic parameters for rennet- and acid-induced milk coagulation using genomic relationships. This is the first time that genetic parameters have been estimated for acid-induced coagulation properties in any dairy cattle breed and for rennet-induced coagulation properties in SR. In addition, milk composition traits were analyzed to elucidate genetic correlations between these traits and milk coagulation properties. Even though this study is based on a limited number of animals, the results generated will give an indication of results to expect in a larger sample.

\section{Heritability Estimates}

Coefficients of variation were relatively high for the coagulation properties (0.2 to 0.8) and somewhat lower for the milk composition traits (0.0 to 0.3 ). Rennetinduced coagulation properties had moderately high heritability estimates, with a somewhat higher esti- 
mate for $\mathrm{G}^{\prime}$ than for YS (Table 1). Other studies have reported heritabilities ranging between 0.11 and 0.41 for rennet G' (Tyrisevä et al., 2004; Comin et al., 2005; Vallas et al., 2010), whereas the heritability estimate for $\mathrm{G}^{\prime}{ }_{\text {rennet }}$ in this study was higher. The present study differs from the previous studies in regard to breed, rheological instrument, and statistical analyses. The most important genetic factor within species is breed, which thus influences the results obtained (De Marchi et al., 2007; Bittante et al., 2012). Furthermore, different analytical techniques for measuring coagulation properties will yield somewhat different traits. In contrast to other studies, the current study also estimated heritability for $\mathrm{YS}_{\text {rennet}}$, which was shown to be moderate (Table 1). Both $\mathrm{G}^{\prime}$ and YS can be used to define gel properties, albeit in different ways: $\mathrm{G}^{\prime}$ gives information about small deformation properties by measuring the strength and number of bonds in the protein gel network, whereas YS gives information about large deformation properties by measuring the proneness of the gel strands to break (Lucey, 2002; Mishra et al., 2005). Hence, YS reflects when cheese is cut and set yogurt is pumped.

The amount of genetic variation for $\mathrm{NC}_{\text {rennet }}$ was relatively high in relation to total phenotypic variation, as indicated by the heritability of 0.45 (Table 1). Earlier studies have reported NC milk in SR (Hallén et al., 2007; Poulsen et al., 2013), thus making it an interesting property to consider in genetic studies. The high heritability for $\mathrm{NC}_{\text {rennet }}$ in this study was higher than reported previously in Finnish Ayrshire (0.26; Ikonen et al., 2004), when curd firmness was used as the binary trait. The high heritability for NC milk suggests that this undesirable property for cheese milk could be eliminated through breeding.

As for rennet gels, moderate to high heritability estimates were found for $\mathrm{G}_{\text {acid }}$ and $\mathrm{YS}_{\text {acid }}$ in acid milk gels (Table 1). No heritability estimates for these properties have been found in the literature; however, effects of protein genetic variants on acid milk coagulation have been reported (Allmere et al., 1998; Bikker et al., 2000; Hallén et al., 2009), suggesting a genetic influence on acid milk coagulation. An interesting observation was that heritability was high for ARC, contrary to expectations, given the small data set. High heritability estimates for acid-induced coagulation properties indicate that these properties can be altered to improve raw milk quality for yogurt production through breeding. Heritability estimates for milk composition traits ranged from 0.15 (lactose content) to 0.59 (relative concentration of $\beta$-LG), which is in the range previously reported (Schopen et al., 2009; Penasa et al., 2010; Tiezzi et al., 2013).

\section{Genetic and Phenotypic Correlations Among Milk Coagulation Properties}

Both $\mathrm{G}^{\prime}$ and YS were strongly and favorably correlated with each other, when rennet or acid was used to induce coagulation (Table 2). This was expected because both these rheological parameters can be used to define gel properties. The traits $\mathrm{G}_{\text {rennet }}$ and $\mathrm{YS}_{\text {rennet }}$ were moderately to strongly correlated with $\mathrm{NC}_{\text {rennet }}$, indicating that higher $\mathrm{G}_{\text {rennet }}^{\prime}$ and $\mathrm{YS}_{\text {rennet }}$ are associated with a lower probability of NC (Table 2). In cheese production, it is important that the gel is firm enough at the time of cutting and therefore it is beneficial to have high values of $\mathrm{G}_{\text {rennet }}$ and $\mathrm{YS}_{\text {rennet }}$ (Walstra et al., 2006; Lucey, 2009). Because NC is an unfavorable property, a decrease in the mean of $\mathrm{NC}_{\text {rennet }}$ as defined within this study is desirable; the negative genetic correlations of $\mathrm{NC}_{\text {rennet }}$ with $\mathrm{G}_{\text {rennet }}^{\prime}$ and $\mathrm{YS}_{\text {rennet }}$ are therefore favorable. However, because the genetic correlation between $\mathrm{NC}_{\text {rennet }}$ and $\mathrm{G}_{\text {rennet }}^{\prime}$ is stronger than that between $\mathrm{NC}_{\text {rennet }}$ and $\mathrm{YS}_{\text {rennet }}, \mathrm{G}^{\prime}$ rennet would be the best indicator for overall improvement of rennet coagulation. This suggests that when breeding toward higher $\mathrm{G}_{\text {rennet }}^{\prime}$, fewer milk samples can be expected to be noncoagulating and $\mathrm{YS}_{\text {rennet }}$ should increase. To our knowledge, no genetic correlations with YS have been reported in the literature. Studies have, however, reported genetic correlations between -0.78 and -0.98 for rennet CT and rennet $\mathrm{G}^{\prime}$ (Cassandro et al., 2008; Bonfatti et al., 2011; Cecchinato et al., 2011), indicating strong genetic correlations between rennet coagulation properties.

Phenotypic correlations revealed a similar pattern as genetic correlations but were generally weaker (Table 2 ). The phenotypic correlations for $\mathrm{NC}_{\text {rennet }}$ with $\mathrm{G}_{\text {rennet }}$ and $\mathrm{YS}_{\text {rennet }}$ were weak but significant. This would be expected because $\mathrm{G}_{\text {rennet }}^{\prime}$ and $\mathrm{YS}_{\text {rennet }}$ are 0 when $\mathrm{NC}_{\text {rennet }}$ is 1 but vary in strength for all $\mathrm{NC}_{\text {rennet }}$ equaling 0 . The phenotypic correlation between $\mathrm{G}_{\text {rennet }}$ and $\mathrm{YS}_{\text {ren- }}$ net found in the present study agreed well with Mishra et al. (2005), who showed that the correlation coefficient between storage modulus $\left(\mathrm{G}^{\prime}\right)$ and YS was 0.87 .

High $\mathrm{G}^{\prime}{ }_{\text {acid }}$ and $\mathrm{YS}_{\text {acid }}$ as well as high ARC are desirable in the production of fermented products. The strong phenotypic correlation between $\mathrm{G}_{\text {acid }}^{\prime}$ and $\mathrm{YS}_{\text {acid }}$ and the weak but significant $(P<0.05)$ and positive correlation of ARC with $\mathrm{G}_{\text {acid }}^{\prime}$ and $\mathrm{YS}_{\text {acid }}$ were expected because these properties are related to each other (Table 2 ). The ARC is an indirect measure of the fermentation kinetics: this property shows the rate of the acidification process when GDL is hydrolyzed to gluconic acid and the $\mathrm{pH}$ is decreased (de Kruif, 1997). Therefore, the strength of a gel at a certain time of coagulation 
Table 2. Genetic (above diagonal) and phenotypic (below diagonal) correlations (standard errors in subscript) among rennet- and acid-induced coagulation properties ${ }^{1}$

\begin{tabular}{|c|c|c|c|c|c|c|}
\hline Trait $^{2}$ & $\mathrm{NC}_{\text {rennet }}$ & $\mathrm{G}_{\text {rennet }}^{\prime}$ & $\mathrm{YS}_{\text {rennet }}$ & $\mathrm{G}_{\text {acid }}^{\prime}$ & $\mathrm{YS}_{\text {acid }}$ & $\mathrm{ARC}$ \\
\hline $\mathrm{NC}_{\text {rennet }}$ & & $\mathbf{- 0 . 8 2} 0.16$ & $\mathbf{- 0 . 4 8} 0.20$ & $0.24_{0.20}$ & $0.15_{0.25}$ & $0.03_{0.17}$ \\
\hline $\mathrm{G}_{\text {rennet }}^{\prime}(\mathrm{Pa})$ & $-\mathbf{0 . 4 0} 0_{0.07}$ & & $\mathbf{0 . 8 9} 0.07$ & $0.11_{0.20}$ & $0.25_{0.23}^{0.23}$ & $0.00_{0.29}$ \\
\hline $\mathrm{YS}_{\text {rennet }}(\mathrm{Pa})$ & $-\mathbf{0 . 2 1}$ & $\mathbf{0 . 8 3 _ { 0 . 0 2 }}$ & & $\mathbf{0 . 4 5}$ & $\mathbf{0 . 5 4} 4_{0.25}$ & $-0.12_{0.35}$ \\
\hline $\mathrm{G}_{\text {acid }}^{\prime}(\mathrm{Pa})$ & $\mathbf{0 . 1 4}$ & $\mathbf{0 . 1 3}$ & $\mathbf{0 . 2 6}{ }_{0.06}$ & & $\mathbf{0 . 9 9} 9_{0.07}$ & $\mathbf{0 . 5 6} \boldsymbol{6}_{0.24}$ \\
\hline $\mathrm{YS}_{\text {acid }}(\mathrm{Pa})$ & $0.09_{0.06}$ & $\mathbf{0 . 3 1}{ }_{0.06}$ & $\mathbf{0 . 4 0} 0_{0.05}$ & $\mathbf{0 . 7 4 _ { 0 . 0 3 }}$ & & $0.50_{0.32}$ \\
\hline $\operatorname{ARC}\left(\mathrm{s}^{-1}\right)$ & $0.02_{0.12}$ & $-0.02_{0.12}$ & $0.02_{0.11}$ & $\mathbf{0 . 3 2} 0.10$ & $\mathbf{0 . 1 8} 0.10$ & \\
\hline
\end{tabular}

${ }^{1}$ Values in bold deviated by more than $1.645 \times \mathrm{SE}$ from $0(P<0.05)$; values in italics deviated by more than $1.282 \times \mathrm{SE}$ from $0(P<0.10)$.

${ }^{2} \mathrm{NC}_{\text {rennet }}$ is a binary trait, where $0=$ coagulated, $1=$ noncoagulated; $\mathrm{G}^{\prime}=$ gel strength; $\mathrm{YS}=$ yield stress; ARC $=$ acidification rate constant.

depends on the ARC. As the ARC showed a significant genetic correlation with $\mathrm{G}^{\prime}$ acid but only a tendency to correlate with $\mathrm{YS}_{\text {acid }}(P<0.10$; Table 2), measurements of $\mathrm{G}^{\prime}$ acid could be used if cows were bred for optimal milk for production of fermented products.

The genetic correlations between rennet-induced and acid-induced coagulation properties were weak, with the exception of $\mathrm{YS}_{\text {rennet }}$ with $\mathrm{G}_{\text {acid }}^{\prime}$ and $\mathrm{YS}_{\text {acid }}$ (Table 2 ). At present, there is no differentiation of milk delivered to Swedish dairies; hence, it is of great interest that the milk is suitable for production of both cheese and fermented products. The moderate genetic correlations identified here suggest that it would be possible to improve $\mathrm{G}^{\prime}$ and YS of rennet- and acid-induced gels simultaneously through breeding. The formation of rennet and acid gels differs in regard to several factors. Milk is pretreated with higher temperatures before gel formation for acid gels compared with rennet gels. Aggregation in acid gels is initiated by acidification, whereas it is induced enzymatically in rennet gels. Moreover, the protein network in acid gels consists of both $\mathrm{CN}$ and $\beta-\mathrm{LG}$, whereas only $\mathrm{CN}$ is present in a rennet gel network (Walstra et al., 2006; Lucey, 2009). Thus, the phenotypic correlations between these gel properties may not be strong. Predictably, the results presented in this study showed that coagulation properties for rennet and acid gels were weakly positively correlated (Table 2), suggesting that it might be possible to use the same milk for both cheese and fermented products. The NC milk that posed a problem in rennet coagulation was not found to be genetically correlated with acid gel properties (Table 2), indicating that the NC milk problem could be solved genetically without impairing acid coagulation properties.

\section{Genetic and Phenotypic Correlations Among Milk Coagulation Properties and Milk Composition}

A moderately strong genetic correlation was found between fat content and $\mathrm{G}_{\text {rennet }}$ and $\mathrm{YS}_{\text {rennet }}$ (Table 3), even though fat had been removed before coagulation was induced. Lemay et al. (2009) presented several candidate genes for protein and fat contents and reported that many of these genes are the same for both traits; for example, the CN genes. Thus, in a similar way, an underlying genetic factor might affect both fat content and coagulation properties.

A moderate unfavorable genetic correlation was observed between $\mathrm{NC}_{\text {rennet }}$ and protein content (Table 3). To our knowledge, this is the first time this genetic correlation has been reported. Ikonen et al. (2004) reported nonlinear phenotypic associations between milk coagulation properties and protein or $\mathrm{CN}$ content, but such nonlinearity was not observed in our data. The unfavorable genetic correlation suggests that breeding for higher protein content could increase problems with NC milk in the SR population. As $18 \%$ of the cows in this sample set had NC milk, it is evident that a robust breeding program taking various milk production traits and properties into account is needed in order to not further increase the frequency of $\mathrm{NC}$ milk in the SR population. Frederiksen et al. (2011a) showed that $25 \%$ NC milk in a batch of milk with good coagulation was enough to have a strong negative effect on rennet coagulation properties. An increased frequency of NC milk could therefore lead to decreased cheese yield, which would have a large economic impact for the dairy industry.

Contrary to expectations, we did not find a genetic association between protein content and other investigated rennet-induced coagulation properties, but we did find a significant genetic correlation with $\mathrm{CN}$ content for $\mathrm{YS}_{\text {rennet }}$ and relative concentration of $\kappa-\mathrm{CN}$ for both $\mathrm{G}_{\text {rennet }}^{\prime}$ and $\mathrm{YS}_{\text {rennet }}$ (Table 3). Inconsistencies exist among earlier studies regarding the genetic correlation between total protein content and rennet $\mathrm{G}^{\prime}$, with correlations between -0.24 and 0.48 (Ikonen et al., 1999; Cassandro et al., 2008; Vallas et al., 2010). In the present study, only a tendency toward a weak positive genetic correlation $(P<0.10)$ between pro- 
Table 3. Genetic correlations (standard errors in subscript) of rennet- and acid-induced coagulation with milk composition traits ${ }^{1}$

\begin{tabular}{|c|c|c|c|c|c|c|}
\hline \multirow[b]{2}{*}{ Composition trait } & \multicolumn{6}{|c|}{ Coagulation trait $^{2}$} \\
\hline & $\mathrm{NC}_{\text {rennet }}$ & $\mathrm{G}_{\text {rennet }}^{\prime}$ & $\mathrm{YS}_{\text {rennet }}$ & $\mathrm{G}_{\text {acid }}^{\prime}$ & $\mathrm{YS}_{\text {acid }}$ & $\mathrm{ARC}$ \\
\hline Milk yield (kg) & $0.01_{0.35}$ & $-0.11_{0.36}$ & $-0.16_{0.40}$ & $-\mathbf{0 . 6 1} 1_{0.32}$ & $-0.71_{0.45}$ & $-0.41_{0.43}$ \\
\hline Protein $(\mathrm{g} / 100 \mathrm{~g})$ & $\mathbf{0 . 3 8} 0.22$ & 0.090 .22 & $0.33_{0.22}$ & $\mathbf{0 . 8 5}$ & $\mathbf{0 . 9 3} 0.26$ & $0.12_{0.35}$ \\
\hline $\mathrm{CN}(\mathrm{g} / 100 \mathrm{~g})$ & $0.16_{0.29}$ & $0.28 \quad 0.25$ & $\mathbf{0 . 5 4} 4_{0.25}$ & $\mathbf{0 . 8 3} \mathbf{3}_{0.22}$ & $\mathbf{0 . 8 9}$ & $-0.10_{0.34}$ \\
\hline Fat $(\mathrm{g} / 100 \mathrm{~g})$ & $-0.37_{0.28}$ & $\mathbf{0 . 6 0} 0.28$ & $\mathbf{0 . 5 2} 0.29$ & $0.20_{0.26}$ & $0.23_{0.32}$ & $0.24_{0.39}$ \\
\hline Lactose $(\mathrm{g} / 100 \mathrm{~g})$ & $-0.33_{0.38}$ & $0.15_{0.41}$ & $0.20_{0.46}$ & -0.330 .49 & $-0.55_{0.68}$ & $-0.57_{0.59}$ \\
\hline$\beta-\mathrm{LG}(\mathrm{wt} / \mathrm{wt} \%)^{3}$ & $\mathbf{- 0 . 4 9} 0.25$ & $0.20_{0.26}^{0.71}$ & $0.09 \quad 0.28$ & $-0.03_{0.22}$ & -0.200 .26 & $0.42_{0.26}$ \\
\hline к-CN (wt/wt\%) & $-0.17_{0.29}$ & $\mathbf{0 . 5 6} \boldsymbol{6}_{0.30}$ & $\mathbf{0 . 7 2} 0.35$ & $\mathbf{0 . 5 1} 0.24$ & $\mathbf{0 . 7 5} 0.28$ & 0.490 .35 \\
\hline
\end{tabular}

${ }^{1}$ Values in bold deviated by more than $1.645 \times$ SE from $0(P<0.05)$; values in italics deviated by more than $1.282 \times \mathrm{SE}$ from $0(P<0.10)$.

${ }^{2} \mathrm{NC}_{\text {rennet }}$ is a binary trait, where $0=$ coagulated, $1=$ noncoagulated; $\mathrm{G}^{\prime}=$ gel strength; $\mathrm{YS}=$ yield stress; ARC $=$ acidification rate constant

${ }^{3}$ Weight per total protein weight.

tein content and $\mathrm{YS}_{\text {rennet }}$ was found, which is within the range of what was previously reported for rennet G'. Interestingly, Cecchinato et al. (2011) found breed differences in genetic correlations between protein content and rennet $\mathrm{G}^{\prime}$ when comparing Brown Swiss and Holstein-Friesian cows, which could explain the inconsistencies between the studies, as different breeds were investigated. However, it seems that the CN fraction of the total milk protein (i.e., $\mathrm{CN}$ content and relative concentration of $\kappa-\mathrm{CN}$ ) has a stronger genetic correlation with rennet-induced coagulation properties and thus could be a promising indicator for genetic improvement of rennet coagulation properties. This is further supported by considering that the $\mathrm{CN}$ fraction forms rennet gels, in which $\kappa$-CN plays an important role (Lucey, 2009). Bonfatti et al. (2011) studied the genetic correlations between rennet-induced coagulation properties and relative concentration of $\kappa$-CN per total $\mathrm{CN}$ and found the genetic correlation for rennet $\mathrm{G}^{\prime}$ to be 0.36 . As in the present study, Bonfatti et al. (2011) argued that rennet coagulation properties could be improved by increasing the content of $\kappa$ - $\mathrm{CN}$ through selective breeding. However, it should be noted that composite $\beta-\kappa-C N$ genotypes do not explain all genetic variance of rennet-induced coagulation properties (Penasa et al., 2010).

For acid gels, protein content was, on the other hand, favorably genetically correlated with acid-induced coagulation properties (Table 3). Both total $\mathrm{CN}$ content and relative concentration of $\kappa-\mathrm{CN}$ showed strong correlations with acid-induced coagulation properties (Table 3 ). This suggests that today's Nordic breeding program is beneficial for breeding toward optimal properties for production of fermented products through selection for protein content. However, as breeding for higher protein content could lead to more problems with NC milk (Table 3), the current breeding program is incomplete regarding milk quality. Even though the heritability estimate for ARC was high, this trait showed only tendencies $(P<0.10)$ to be genetically correlated with relative concentrations of $\beta-\mathrm{LG}$ and $\kappa-\mathrm{CN}$. However, these results are expected considering the presence of both $\beta$-LG and $\kappa$-CN in the acid gel protein network (Lucey, 2009), and the lack of significance might be due to the small sample set.

Phenotypic correlations were significant for most of the combinations with significant genetic correlations, with the exception of milk yield with acid-induced coagulation properties and protein content with $\mathrm{NC}_{\text {rennet }}$ (Table 4). Phenotypic correlations were generally weaker than genetic correlations. As expected, protein and $\mathrm{CN}$ contents as well as relative concentration of $\kappa-\mathrm{CN}$ were phenotypically correlated with both rennet-induced coagulation (Wedholm et al., 2006; Amenu and Deeth, 2007; Frederiksen et al., 2011b) and acid-induced coagulation (Lucey and Singh, 1998; Allmere et al., 1999; Hallén et al., 2009).

Milk production traits included in the Nordic breeding program are yields of milk, protein, and fat, with a negative weight for milk yield, thus favoring high protein and fat contents (Nordic Cattle Genetic Evaluation, 2013). Consequently, an unfavorable correlation between these traits and coagulation properties could adversely affect production of cheese and fermented products. The estimated negative genetic correlations between milk yield and $\mathrm{G}_{\text {acid }}^{\prime}(P<0.05)$ as well as $\mathrm{YS}_{\text {acid }}(P<0.10$; Table 3$)$ suggest that breeding for increased milk yield would lead to a deterioration of acid-induced coagulation. However, this is in contrast to the results obtained for rennet-induced coagulation in the present study, where no significant genetic correlations were found (Table 3). Previous studies have reported no or weak genetic correlation between milk yield and rennet $\mathrm{G}^{\prime}$ (Ikonen et al., 1999; Cassandro 
Table 4. Phenotypic correlations (standard errors in subscript) of rennet- and acid-induced coagulation with milk composition traits ${ }^{1}$

\begin{tabular}{|c|c|c|c|c|c|c|}
\hline \multirow[b]{2}{*}{ Composition trait } & \multicolumn{6}{|c|}{ Coagulation trait $^{2}$} \\
\hline & $\mathrm{NC}_{\text {rennet }}$ & $\mathrm{G}_{\text {rennet }}^{\prime}$ & $\mathrm{YS}_{\text {rennet }}$ & $\mathrm{G}_{\text {acid }}^{\prime}$ & $\mathrm{YS}_{\text {acid }}$ & $\mathrm{ARC}$ \\
\hline Milk yield (kg) & $-0.02_{0.06}$ & $-\mathbf{0 . 1 1 _ { 0 . 0 6 }}$ & $-\mathbf{0 . 1 6} 6_{0.06}$ & $-0.07_{0.06}$ & $0.00_{0.06}$ & $-0.08_{0.10}$ \\
\hline Protein (g/100 g) & $-0.01_{0.06}$ & $\mathbf{0 . 2 5}$ & $\mathbf{0 . 4 0} 0.06$ & $\mathbf{0 . 3 6} \mathbf{6}_{0.05}$ & $\mathbf{0 . 2 5} \mathbf{5}_{0.06}$ & $-0.12_{0.10}$ \\
\hline $\mathrm{CN}(\mathrm{g} / 100 \mathrm{~g})$ & $-\mathbf{0 . 1 0} 0_{0.06}$ & $\mathbf{0 . 3 5} 0.06$ & $\mathbf{0 . 4 5} 0.05$ & $\mathbf{0 . 4 3} \mathbf{3}_{0.05}$ & $\mathbf{0 . 2 7} 7_{0.05}$ & $-0.16_{0.11}$ \\
\hline Fat $(\mathrm{g} / 100 \mathrm{~g})$ & $-0.05_{0.06}^{0.00}$ & $\mathbf{0 . 2 1} 0.06$ & $\mathbf{0 . 2 6}$ & $\mathbf{0 . 2 1}$ & $\mathbf{0 . 1 7} 0.06$ & -0.080 .11 \\
\hline Lactose $(\mathrm{g} / 100 \mathrm{~g})$ & $\mathbf{- 0 . 1 1 _ { 0 . 0 6 }}$ & $\mathbf{0 . 1 1 _ { 0 . 0 6 }}$ & $0.09_{0.06}$ & $0.04_{0.06}$ & $0.06_{0.06}$ & -0.030 .11 \\
\hline$\beta-\mathrm{LG}(\mathrm{wt} / \mathrm{wt} \%)^{3}$ & $\mathbf{- 0 . 1 4} 0.06$ & $0.05_{0.07}^{0.00}$ & $0.01_{0.07}$ & $-0.02_{0.07}$ & $\mathbf{- 0 . 1 8} 0.06$ & $\mathbf{0 . 1 8} 0.10$ \\
\hline k-CN (wt/wt\%) & $\mathbf{- 0 . 1 3} 0.06$ & $\mathbf{0 . 2 9} 0.07$ & $\mathbf{0 . 3 1 _ { 0 . 0 6 }}$ & $\mathbf{0 . 2 5} \mathbf{5}_{0.06}$ & $\mathbf{0 . 2 7} 0.06$ & 0.090 .11 \\
\hline
\end{tabular}

${ }^{1}$ Values in bold deviated by more than $1.645 \times \mathrm{SE}$ from $0(P<0.05)$; values in italics deviated by more than $1.282 \times \mathrm{SE}$ from $0(P<0.10)$.

${ }^{2} \mathrm{NC}_{\text {rennet }}$ is a binary trait, where $0=$ coagulated, $1=$ noncoagulated; $\mathrm{G}^{\prime}=$ gel strength; $\mathrm{YS}=$ yield stress; ARC $=$ acidification rate constant.

${ }^{3}$ Weight per total protein weight.

et al., 2008; Cecchinato et al., 2011), suggesting that rennet-induced coagulation would not be affected negatively when breeding toward higher milk yields.

\section{Genetic Analyses and Statistical Methods}

This study is among the first to estimate genetic parameters for milk quality traits based on genomic relationship coefficients instead of using pedigree-based relationship coefficients. The use of genomic relationship information has the advantage of obtaining more precise estimates (lower SE; Ødegård and Meuwissen, 2012). In addition, estimates are not affected by errors in pedigree recording, which typically leads to underestimation of genetic parameters (Geldermann et al., 1986). In human genetic studies, the use of genomic relationship information has led to lower estimates of heritabilities compared with pedigree-based heritabilities (the so-called missing heritability; Maher, 2008), but this phenomenon has not been as clearly observed in animal genetic studies. Haile-Mariam et al. (2013) and Veerkamp et al. (2011) compared pedigree-based and genomic-based heritabilities and found that the latter resulted in, on average, $20 \%$ lower heritabilities. Jensen et al. (2012), on the other hand, found smaller differences, around $5 \%$ on average. The heritabilities for test-day observations for milk yield presented in this study (Table 1) are similar to previous estimates of heritabilities in the SR population (Lidauer et al., 2009). Even though the current study was based on a limited number of animals, the results generated may serve as an indication of expected results in larger experiments.

Ignoring NC samples in the estimation of genetic parameters for rennet coagulation properties may lead to biased estimates (Cecchinato and Carnier, 2011). This was circumvented by including a trait, $\mathrm{NC}_{\text {rennet }}$, in the analyses, and may be one of the reasons for differences between our results and those of other studies. For example, ignoring noncoagulating milk samples led to lower heritability estimates for curd firmness in the study of Ikonen et al. (2004). Similarly, the presence of NC milk as such may result in different magnitudes of (genetic) associations between milk composition and milk coagulation properties in the SR breed compared with other breeds.

\section{CONCLUSIONS}

This study reported estimates of genetic parameters for rennet- and acid-induced milk coagulation using genomic relationships. The present study was based on a limited number of animals but it is the first time that genetic parameters have been estimated for acidinduced coagulation properties in dairy cattle and for rennet-induced coagulation properties in the Swedish Red breed. Heritability estimates were found to be moderate to high for the investigated milk coagulation properties and compositional traits. The high heritability for NC milk suggests that this property could be eliminated through breeding. Furthermore, genetic correlations between acid- and rennet-induced coagulation properties were found to be favorable, suggesting that both these traits could be improved simultaneously. The current Nordic breeding program could lead to more problems with $\mathrm{NC}$ milk and a deterioration of acid-induced coagulation through unfavorable genetic associations with protein content and milk yield, respectively. An increased frequency of $\mathrm{NC}$ milk could lead to decreased cheese yield which would have a large economic impact for the dairy industry. The results presented here indicate the potential to improve milk used for production of cheese and fermented products either directly by including milk coagulation properties 
or indirectly by including compositional traits (e.g., CN content and relative concentration of $\kappa-\mathrm{CN}$ ) genetically associated with milk coagulation in national breeding programs. However, milk is a complex fluid that is used not only for production of cheese and fermented products but also for several other dairy products (e.g., liquid milk, butter, and milk powder). Therefore, it is important to know how every end product is affected by the breeding objective so that milk is not altered detrimentally for some of the products. Further research is thus needed to elucidate genetic parameters for technological properties of other dairy products.

\section{ACKNOWLEDGMENTS}

The authors thank Hany Abd Elmontaleb at the Department of Food Technology, Engineering and Nutrition, Lund University (Lund, Sweden) for help with the calorimetric measurements. The present work was supported by grants from the Swedish Farmer's Foundation for Agricultural Research (SLF; Stockholm, Sweden), TvärLivs [cooperation between the Swedish Research Council for Environment, Agricultural Sciences and Spatial Planning (FORMAS), Swedish Governmental Agency for Innovation Systems (VINNOVA), SLF, Livsmedelsföretagen (Li). and Svensk Dagligvaruhandel; Stockholm, Sweden], Arla Foods amba (Viby J, Denmark), and the Danish Strategic Research Council.

\section{REFERENCES}

Allmere, T., M. Åkerlind, and A. Andrén. 1999. Rheological properties of acidified gels on skim milk from cows selected for high or low milk fat concentration. Int. Dairy J. 9:703-707.

Allmere, T., A. A. Andrén, M. Lindersson, and L. Björck. 1998. Studies on rheological properties of stirred milk gels made from milk with defined genetic variants of $\kappa$-casein and $\beta$-lactoglobulin. Int Dairy J. 8:899-905.

Amenu, B., and H. C. Deeth. 2007. The impact of milk composition on cheddar cheese manufacture. Aust. J. Dairy Technol. 62:171-184.

Bikker, J. F., S. G. Anema, and J. P. Hill. 2000. Rheological properties of acid gels prepared from heated milk fortified with whey protein mixtures containing the $\mathrm{A}, \mathrm{B}$ and $\mathrm{C}$ variants of $\beta$-lactoglobulin. Int. Dairy J. 10:723-732.

Bittante, G., M. Penasa, and A. Cecchinato. 2012. Invited review: Genetics and modeling of milk coagulation properties. J. Dairy Sci. 95:6843-6870.

Boichard, D., and M. Brochard. 2012. New phenotypes for new breeding goals in dairy cattle. Animal 6:544-550.

Bonfatti, V., A. Cecchinato, L. Gallo, A. Blasco, and P. Carnier. 2011. Genetic analysis of detailed milk protein composition and coagulation properties in Simmental cattle. J. Dairy Sci. 94:5183-5193.

Browning, S. R., and B. L. Browning. 2007. Rapid and accurate haplotype phasing and missing data inference for whole genome association studies using localized haplotype clustering. Am. J. Hum. Genet. 81:1084-1097.

Cassandro, M., A. Comin, M. Ojala, R. Dal Zotto, M. De Marchi, L. Gallo, P. Carnier, and G. Bittante. 2008. Genetic parameters of milk coagulation properties and their relationships with milk yield and quality traits in Italian Holstein cows. J. Dairy Sci. 91:371-376.
Cecchinato, A., and P. Carnier. 2011. Short communication: Statistical models for the analysis of coagulation traits using coagulating and noncoagulating milk information. J. Dairy Sci. 94:4214-4219.

Cecchinato, A., M. Penasa, M. De Marchi, L. Gallo, G. Bittante, and P. Carnier. 2011. Genetic parameters of coagulation properties, milk yield, quality, and acidity estimated using coagulating and noncoagulating milk information in Brown Swiss and HolsteinFriesian cows. J. Dairy Sci. 94:4205-4213.

Comin, A., M. Cassandro, M. Povinelli, and G. Bittante. 2005. Genetic aspects of milk coagulation properties in Italian Holstein cows. Ital. J. Anim. Sci. 4:10-12.

Dalgleish, D. G. 1992. The enzymatic coagulation of milk. Pages 579619 in Advanced Dairy Chemistry. Vol. 1: Proteins. P. F. Fox, ed. Elsevier Science Publishers Ltd., London, UK.

de Kruif, C. G. 1997. Skim milk acidification. J. Colloid Interface Sci. 185:19-25.

De Marchi, M., R. Dal Zotto, M. Cassandro, and G. Bittante. 2007. Milk coagulation ability of five dairy cattle breeds. J. Dairy Sci. 90:3986-3992.

Frederiksen, P. D., K. K. Andersen, M. Hammersh øj, H. D. Poulsen, J. Sørensen, M. Bakman, K. B. Qvist, and L. B. Larsen. 2011a. Composition and effect of blending of noncoagulating, poorly coagulating, and well-coagulating bovine milk from individual Danish Holstein cows. J. Dairy Sci. 94:4787-4799.

Frederiksen, P. D., M. Hammershoj, M. Bakman, P. N. Andersen, J. B. Andersen, K. B. Qvist, and L. B. Larsen. 2011b. Variations in coagulation properties of cheese milk from three Danish dairy breeds as determined by a new free oscillation rheometry-based method. Dairy Sci. Technol. 91:309-321.

Geldermann, H., U. Pieper, and W. E. Weber. 1986. Effect of misidentification on the estimation of breeding value and heritability in cattle. J. Anim. Sci. 63:1759-1768.

Gilmour, A. R., B. J. Gogel, B. R. Cullis, and R. Thompson. 2009. ASReml User Guide Release 3.0. VSN International Ltd., Hemel Hempstead, UK. www.vsni.co.uk.

Glantz, M., H. Lindmark Månsson, H. Stålhammar, L.-O. Bårström, M. Fröjelin, A. Knutsson, C. Teluk, and M. Paulsson. 2009. Effects of animal selection on milk composition and processability. J. Dairy Sci. 92:4589-4603.

Glantz, M., H. Lindmark Mansson, H. Stalhammar, and M. Paulsson. 2011. Effect of polymorphisms in the leptin, leptin receptor, and acyl-coenzyme A:diacylglycerol acyltransferase 1 (DGAT1) genes and genetic polymorphism of milk proteins on cheese characteristics. J. Dairy Sci. 94:3295-3304.

Gustavsson, F., A. J. Buitenhuis, M. Johansson, H. P. Bertelsen, M. Glantz, N. A. Poulsen, H. Lindmark Månsson, H. Stålhammar, L. B. Larsen, C. Bendixen, M. Paulsson, and A. Andrén. 2014. Effects of breed and casein genetic variants on protein profile in milk from Swedish Red, Danish Holstein, and Danish Jersey cows. J. Dairy Sci. 97:3866-3877.

Guyomarc'h, F., A. J. Law, and D. G. Dalgleish. 2003. Formation of soluble and micelle-bound protein aggregates in heated milk. J. Agric. Food Chem. 51:4652-4660.

Haile-Mariam, M., G. J. Nieuwhof, K. T. Beard, K. V. Konstatinov, and B. J. Hayes. 2013. Comparison of heritabilities of dairy traits in Australian Holstein-Friesian cattle from genomic and pedigree data and implications for genomic evaluations. J. Anim. Breed. Genet. 130:20-31.

Hallén, E., T. Allmere, A. Lundén, and A. Andrén. 2009. Effect of genetic polymorphism of milk proteins on rheology of acid-induced milk gels. Int. Dairy J. 19:399-404.

Hallén, E., T. Allmere, J. Näslund, A. Andrén, and A. Lundén. 2007. Effect of genetic polymorphism of milk proteins on rheology of chymosin-induced milk gels. Int. Dairy J. 17:791-799.

Ikonen, T., K. Ahlfors, R. Kempe, M. Ojala, and O. Ruottinen. 1999 Genetic parameters for the milk coagulation properties and prevalence of noncoagulating milk in Finnish dairy cows. J. Dairy Sci. $82: 205-214$

Ikonen, T., S. Morri, A.-M. Tyrisevä, O. Ruottinen, and M. Ojala. 2004. Genetic and phenotypic correlations between milk coagula- 
tion properties, milk production traits, somatic cell count, casein content, and pH of milk. J. Dairy Sci. 87:458-467.

International Dairy Federation. 2012. The World Dairy Situation 2012. Bulletin 458/2012. International Dairy Federation, Brussels, Belgium.

Jensen, J., G. Su, and P. Madsen. 2012. Partitioning additive genetic variance into genomic and remaining polygenic components for complex traits in dairy cattle. BMC Genet. 13:44.

Lemay, D. G., D. J. Lynn, W. F. Martin, M. C. Neville, T. M. Casey, G. Rincon, E. V. Kriventseva, W. C. Barris, A. S. Hinrichs, A. J. Molenaar, K. S. Pollard, N. J. Maqbool, K. Singh, R. Murney, E. M. Zdobnov, R. L. Tellam, J. F. Medrano, J. B. German, and M. Rijnkels. 2009. The bovine lactation genome: Insights into the evolution of mammalian milk. Genome Biol. 10:R43.

Lidauer, M. H., P. Madsen, K. Matilainen, E. A. Mäntysaari, I. Strandén, R. Thompson, J. Pösö, J. Pedersen, U. S. Nielsen, J.-A. Eriksson, K. Johansson, and G. P. Aamand. 2009. Estimation of variance components for Nordic red cattle test-day model: Bayesian Gibbs sampler vs. Monte Carlo EM REML. Interbull Bull. 40:37-41.

Liu, Y., X. Qin, X. Z. Song, H. Jiang, Y. Shen, K. J. Durbin, S. Lien, M. P. Kent, M. Sodeland, Y. Ren, L. Zhang, E. Sodergren, P. Havlak, K. C. Worley, G. M. Weinstock, and R. A. Gibbs. 2009. Bos taurus genome assembly. BMC Genomics 10:180.

Lucey, J. A. 2002. Formation and physical properties of milk protein gels. J. Dairy Sci. 85:281-294.

Lucey, J. A. 2009. Milk protein gels. Pages 449-471 in Milk ProteinsFrom Expression to Food. Vol. 1. A. Thompson, M. Boland and H. Singh, ed. Elsevier Inc., Burlington, MA.

Lucey, J. A., and H. Singh. 1998. Formation and physical properties of acid milk gels: A review. Food Res. Int. 30:529-542.

Maher, B. 2008. Personal genomes: The case of the missing heritability. Nature 456:18-21.

Mishra, R., S. Govindasamy-Lucey, and J. A. Lucey. 2005. Rheological properties of rennet-induced gels during the coagulation and cutting process: Impact of processing conditions. J. Texture Stud. 36:190-212.

Nordic Cattle Genetic Evaluation. 2013. NAV Routine Genetic Evaluation of Dairy Cattle - Data and Genetic Models. Nordic Cattle Genetic Evaluation, Aarhus, Denmark.

Ødegård, J., and T. H. E. Meuwissen. 2012. Estimation of heritability from limited family data using genome-wide identity-by-descent sharing. Genet. Sel. Evol. 44:16.

Penasa, M., M. Cassandro, D. Pretto, M. De Marchi, A. Comin, S. Chessa, R. Dal Zotto, and G. Bittante. 2010. Short communication: Influence of composite casein genotypes on additive genetic variation of milk production traits and coagulation properties in Holstein-Friesian cows. J. Dairy Sci. 93:3346-3349.

Poulsen, N. A., H. P. Bertelsen, H. B. Jensen, F. Gustavsson, M. Glantz, H. L. Mansson, A. Andren, M. Paulsson, C. Bendixen, A. J. Buitenhuis, and L. B. Larsen. 2013. The occurrence of noncoagulating milk and the association of bovine milk coagulation properties with genetic variants of the caseins in 3 Scandinavian dairy breeds. J. Dairy Sci. 96:4830-4842.

Schopen, G. C., J. M. Heck, H. Bovenhuis, M. H. Visker, H. J. van Valenberg, and J. A. van Arendonk. 2009. Genetic parameters for major milk proteins in Dutch Holstein-Friesians. J. Dairy Sci. 92:1182-1191.

Tiezzi, F., D. Pretto, M. De Marchi, M. Penasa, and M. Cassandro. 2013. Heritability and repeatability of milk coagulation properties predicted by mid-infrared spectroscopy during routine data recording, and their relationships with milk yield and quality traits. Animal 7:1592-1599.

Tyrisevä, A.-M., T. Vahlsten, O. Ruottinen, and M. Ojala. 2004 Noncoagulation of milk in Finnish Ayrshire and Holstein-Friesian cows and effect of herds on milk coagulation ability. J. Dairy Sci. $87: 3958-3966$

Vallas, M., H. Bovenhuis, T. Kaart, K. Pärna, H. Kiiman, and E. Pärna. 2010. Genetic parameters for milk coagulation properties in Estonian Holstein cows. J. Dairy Sci. 93:3789-3796.

VanRaden, P. M. 2008. Efficient methods to compute genomic predictions. J. Dairy Sci. 91:4414-4423.

Veerkamp, R. F., H. A. Mulder, R. Thompson, and M. P. Calus. 2011. Genomic and pedigree-based genetic parameters for scarcely recorded traits when some animals are genotyped. J. Dairy Sci. 94:4189-4197.

Wadsö, L. 2005. Applications of an eight-channel isothermal conduction calorimeter for cement hydration studies. Cement Int. 5:94101.

Wadsö, L. 2010. Operational issues in isothermal calorimetry. Cement Concr. Res. 40:1129-1137.

Wadsö, L., and X. Li. 2008. A simple rate law experiment using a custom-built isothermal heat conduction calorimeter. J. Chem. Educ. 85:112-116.

Walstra, P., J. T. M. Wouters, and T. J. Guerts. 2006. Dairy Science and Technology. 2nd ed. CRC Press (Taylor \& Francis Group), Boca Raton, FL.

Wedholm, A., L. B. Larsen, H. Lindmark Månsson, A. H. Karlsson, and A. Andrén. 2006. Effect of protein composition and the cheese-making properties of milk from individual dairy cows. J. Dairy Sci. 89:3296-3305. 